\title{
Entrepreneurship, economic development and institutions
}

\author{
Zoltan J. Acs $\cdot$ Sameeksha Desai $\cdot$ Jolanda Hessels
}

Accepted: 18 July 2008/Published online: 5 September 2008

(C) The Author(s) 2008. This article is published with open access at Springerlink.com

\begin{abstract}
This paper is an introduction to the special issue from the 3rd Global Entrepreneurship Monitor Research Conference held in Washington, D.C., in 2008. The paper has three objectives. First, to discuss the importance of the three stages of economic development, the factor-driven stage, the efficiency-driven stage and the innovation-driven stage. Second, to examine the empirical evidence on the relationship between stages of economic development and entrepreneurship. Third, to present a summary of the papers in the context of the theory.
\end{abstract}

Keywords Entrepreneurship · Economic Development · Institutions · Public Policy · Innovation

JEL Classifications $\quad \mathrm{L} 26 \cdot \mathrm{O} 1 \cdot \mathrm{O} 3$

Z. J. Acs $(\bowtie) \cdot$ S. Desai

School of Public Policy, George Mason University, Fairfax, VA, USA

e-mail: zacs@gmu.edu

Z. J. Acs - S. Desai

Max Planck Institute of Economics, Jena, Germany

e-mail: desai@econ.mpg.de

J. Hessels

EIM Business and Policy Research, Erasmus University,

Rotterdam, The Netherlands

e-mail: joh@eim.nl

\section{Introduction}

Entrepreneurship is considered to be an important mechanism for economic development through employment, innovation and welfare effects (Schumpeter 1934; Acs and Audretsch 1988; Wennekers and Thurik 1999; Baumol 2002). The dynamics of entrepreneurship can be vastly different depending on institutional context and level of economic development. There are considerable differences across countries in the orientation of entrepreneurial activities (Autio 2007). The nature and structure of entrepreneurial activities varies across countries as reflected by, for example, the relative volumes of necessity and opportunity entrepreneurship. Acs and Varga (2005) studied 11 countries and found that opportunity entrepreneurship has a positive significant effect on economic development, whereas necessity entrepreneurship has no effect.

The environment shaping the economy affects the dynamics of entrepreneurship within any given country. This environment is marked by interdependencies between economic development and institutions, which affect other characteristics, such as quality of governance, access to capital and other resources, and the perceptions of entrepreneurs. Institutions are critical determinants of economic behavior (North 1990) and economic transactions (Williamson 1998) in general, and they can impose direct and indirect effects on both the supply and demand of entrepreneurs. 
Therefore, if one is interested in studying entrepreneurship within or across countries, the broad nexus between entrepreneurship, economic development and institutions is a critical area of inquiry. This nexus is especially important in helping understand why the relative contributions of entrepreneurship can vary significantly across countries and regions.

Understanding this nexus is crucial to gain insight into what can work for economic development. This is for two reasons. First, the international economic development community has learned that a one-sizefits-all approach simply does not work (Easterly 2001). Second, economic importance attributed to "the entrepreneur" and concurrent policy interest in his/her activities has exploded in recent years. This combination suggests that public policy needs to be informed by the dynamics of entrepreneurship and economic development, as well as relevant local institutional conditions and context-specific variables.

The articles in this special issue represent papers presented at the 3rd Global Entrepreneurship Monitor (GEM) research conference. The first conference in Berlin, Germany, focused on variation in entrepreneurial activity in developed countries (Sternberg and Wennekers 2005), while the second conference in Budapest, Hungary, expanded the focus to transition countries (Acs and Szerb 2008). The third conference in Washington, D.C., organized by George Mason University and Babson College, and expanded the focus to developing countries. It was dedicated to the nexus between entrepreneurship, economic development and institutions in the global economy. The next section outlines the relationship between economic development and globalization. Section III focuses on the relationship between entrepreneurship and economic development and asks the question, "How well do existing measures of entrepreneurship measure the relationship between entrepreneurship and economic development?" Section IV summarizes the papers in the special issue, and the concluding section examines the policy implications.

\section{Economic development and globalization}

Porter (1990) and Porter et al. (2002) define competitiveness according to country economic development, distinguishing three specific stages: (1) factor-driven stage, (2) efficiency-driven stage and (3) innovation-driven stage; and two transitions between these stages. Countries in the factor-driven stage compete through low cost efficiencies in the production of commodities or low value-added products. The first stage is marked with high rates of non-agricultural self-employment. Sole proprietorships-i.e., the self-employed-probably account for most small manufacturing firms and service firms. Almost all economies experience this stage. These countries neither create knowledge for innovation nor use knowledge for exporting.

To move into the second stage, the efficiency-driven stage, countries must increase their production efficiency and educate the workforce to be able to adapt in the subsequent technological development phase. To compete in this second stage, countries must have efficient productive practices on large markets, which allow companies to exploit economies of scale. Industries in this stage are manufacturers or provide basic services (Syrquin 1988). The efficiency-driven stage is marked by decreasing rates of self-employment. There are several reasons to expect entrepreneurial activity will decrease as economies become more developed (Kuzents 1966; Schultz 1988). ${ }^{1}$ If we assume individuals have different endowments of managerial ability, then as an economy becomes wealthier, the average firm size should increase as better managers run the companies. Average firm size is an increasing function of the wealth of the economy if capital and labor substitute. When capital and labor are substitutes, an increase in the capital stock increases returns from working and lowers returns from managing.

In other words, marginal managers find they can earn more money when employed by somebody else. In this model of economic development, increases in the capital stock (through private enterprise, direct foreign investment or government ownership) will increase returns to wage work relative to entrepreneurial activity. In this model, the relationship between entrepreneurial activity and economic development would be negative. That is, as the economy becomes more developed, we should find fewer people pursuing entrepreneurial activity. ${ }^{2}$

\footnotetext{
${ }_{1}$ Kuznets observed the tendency for the self-employment rate to decline with economic development.

2 There are other, simpler, explanations for why entrepreneurial activity may decline as economies develop. Improvements
} 
The innovation-driven stage is marked by an increase in entrepreneurial activity. For over a century there has been a trend in economic activity, exhibited in virtually every developed industrialized country, away from small firms and towards larger organizations. It was, therefore, particularly striking when a series of studies identified this trend had not only ceased sometime during the mid 1970s, but had actually begun to reverse itself (Blau 1987; Evans and Leighton 1989). More recent studies have confirmed this result for most developed countries in the 1970 and 1980s (Acs et al. 1994b). The empirical evidence clearly shows that firm size distribution in developed countries began to shift away from larger corporations and towards entrepreneurial activity.

There are three reasons entrepreneurial activity rises in the final stage of economic activity. First, the innovation-driven stage is marked by decreases in the share of manufacturing in the economy. Virtually all industrialized market economies experienced a decline in manufacturing over the last 30 years. The business service sector expanded relative to manufacturing. Service firms are smaller on average than manufacturing firms; therefore, economy-wide average firm size may decline. Moreover, service firms provide more opportunities for entrepreneurship. This is clearly the case in the United States, as well as in several EU countries, including Germany and Sweden.

Second, technological change during the postwar period has been biased towards industries in which entrepreneurial activity is important (Jorgenson 2001). Improvements in information technologies, such as telecommunications, may increase returns to entrepreneurship. Express mail services, photocopying services, personal computers, the internet, web services and mobile phones services make it less expensive and less time consuming for geographically separate individuals to exchange information.

Third, Aquilina et al. (2006) have come to the conclusion that a high value of the elasticity of factor

Footnote 2 continued

in the economy's infrastructure, such as transportation, telecommunications and credit markets, probably increase the advantages of larger firms over smaller firms. Improvements in transportation and telecommunications make it cheaper to distribute goods and services over larger areas. Assuming there are scale economies up to a point, better distribution systems enable firms to operate larger production units that can serve larger markets. substitution not only leads to more per capita capital, but makes it at the same time easier for an individual to become an entrepreneur if the aggregate elasticity of substitution is also negative. In an economy characterized by higher values of the aggregate elasticity of substitution, we should expect a higher level of development, more entrepreneurs and smaller firms.

In recent years, economists have come to recognize the input-completing and gap-filling capacities of entrepreneurial activity in innovation and growth, and the significant contribution of innovation and growth to prosperity and economic welfare (Acs and Armington 2006; Schramm 2006; Audretsch 2007). Therefore, while most developed countries are in the innovation-driven stage, most developing economies, including Brazil, Russia, India and China (BRIC countries), are in the efficiency-driven stage. In addition to differences in the nature of competition across stages, there are also differences in the degree of integration of countries into the world economy. In particular, since innovation contributes to competitive advantage in foreign markets (Roper and Love 2002; Sterlacchini 1999; Wakelin 1998), developed economies are better integrated globally (UNCTAD 2006) and tend to have higher levels of export-oriented entrepreneurship than developing economies (De Clercq et al. 2008). In order for economies to move into the innovation-driven stage, it is necessary for them to develop environmental conditions conducive to entrepreneurship. Several countries have achieved this in the past decade, including Korea, Ireland, Israel and Taiwan to name few (Acs and Szerb 2007).

\section{Entrepreneurship data and economic development}

The Global Entrepreneurship Monitor (GEM) research program is an annual assessment of the national level of entrepreneurial activity. Initiated in 1999 with 10 countries, expanded to 21 in the year 2000 and over 60 countries in 2008, the program covers both developed and developing countries. The research program, based on a harmonized assessment of the level of national entrepreneurial activity for all participating countries, involves exploration of the role of entrepreneurship in national economic growth. Representative samples of randomly selected adults, 
ranging in size from 1,000 to almost 27,000 individuals, are surveyed annually in each participating country to provide harmonized measures of the prevalence of entrepreneurial activity. There is, further, a wealth of national features and characteristics associated with entrepreneurial activity. ${ }^{3}$

The GEM project is unique in that while all countries collect official data on self- employment, the size distribution of firms, census data on all or most plants and firms, firm and plant entry, almost none of these registry sources are comparable across countries, even developed countries. Official data sources differ in the way they define when an establishment enters a file, when it leaves and how they handle self-employment, which makes crossnational comparisons almost impossible. ${ }^{4}$ Therefore, one of the major strengths of the GEM project is the application of uniform definitions and data collection across countries for international comparisons.

The intent of GEM data is to systematically assess two things: The level of start-up activity or the prevalence of nascent firms and the prevalence of new or young firms that have survived the start-up phase. First, start-up activity is measured by the proportion of the adult population (18-64 years of age) in each country that is currently engaged in the process of creating a nascent business. Second, the proportion of adults in each country who are involved in operating a business that is less than 42 months old measures the presence of new firms. The distinction between nascent and new firms is made in order to determine the relationship of each to national economic growth. For both measures, the research focus is on entrepreneurial activity in which the individual involved has a direct, but not necessarily full ownership interest in the business. The GEM model serves as a vehicle to interpret both the data collection process and provide a framework for theory and policy (Levie and Autio 2008).

A major shortcoming of GEM data has been the fact that it has not been able to effectively deal with the 'issue' of how to compare entrepreneurial activity in developed and developing countries. For example,

\footnotetext{
${ }_{3}$ For more information on GEM and all GEM reports please go to: www.gemcomnsortium.org.

${ }^{4}$ For a discussion of the GEM data, see Reynolds et al. 2005. "Global Entrepreneurship Monitor: Data Collection Design and Implementation 1998-2003." Small Business Economics.
}

low-income countries, such as Uganda, Peru and Ecuador, have very high levels of self-employment and therefore, have high levels of entrepreneurial activity as measured by the GEM program. Highincome countries like Japan, Sweden and Germany have much lower levels of entrepreneurial activity as measured by the GEM program.

In order to address this issue for developing countries, GEM researchers started to collect data on both opportunity entrepreneurship (starting a business to exploit a perceived business opportunity) and necessity entrepreneurship (starting a business because you were pushed into it). However, both measures show higher levels in developing countries than in developed countries. Many respondents are probably tempted to state they are pursuing an opportunity rather than being involved in entrepreneurial activities because they have no other option for work, even if the latter statement describes the activity best. Moreover, the relationship between necessity entrepreneurship and economic development is most likely negative in low-income countries, while the relationship between entrepreneurship and economic development in high-income countries is most likely positive. This must be further balanced by the fact that some countries like India and China have high levels of opportunity entrepreneurship, at least in certain parts, and countries like Japan have very low levels of opportunity entrepreneurship and low growth.

Therefore, we would expect that in economies in the early or middle stage of economic development, the efficiency-driven stage, entrepreneurial activity would be negatively related to economic development since most people would be trying to move from self-employment to wage employment. In developed economies, we would expect entrepreneurial activity to be positively related to economic development as people shift from wage work to entrepreneurial activity, the innovation driven stage. This framework seems to imply that a U-shaped relationship may in fact exist between entrepreneurial activity and economic development in the global economy. Countries like Uganda, Peru and Ecuador are all countries with high levels of entrepreneurial activity-but low levels of per capita income. Countries with much lower levels of entrepreneurial activity, for example, Brazil and Argentina, appear to have higher levels of per capita income and are moving 
toward lower levels of entrepreneurial activity. The middle represents a set of countries that appear to be transitioning from a middle-income level to a higher income level, and some have rising levels of entrepreneurial activity. High-income countries, such as Germany, France, Belgium, Italy and Finland, have relatively low levels of entrepreneurial activity. Two countries stand out as outliers: Japan, with one of the lowest levels of entrepreneurial activity, and the United States, with one of the highest levels of entrepreneurial activity.

The story for developed countries is different and has its origins in the work of David Blau (1987), who was the first to document the upturn in self-employment rates after they declined for the better part of a century. There is tremendous diversity in the level and time-series pattern of entrepreneurship across countries. They show that the major explanation for this diversity is the stage of economic development. They also show that the negative relationship between entrepreneurship and economic development remains after controlling for a number of other factors. Although economic development is an extremely powerful force behind the secular decline in entrepreneurship, the convergence of several factors in the $1970 \mathrm{~s}$ tended to stem the secular decline in entrepreneurship for many countries. Of 23 OECD countries examined by Acs et al. (1994b), 15 had a U-shaped relationship during the 1970s or 1980s.

What caused the upturn in small-scale economic activity? Acs et al. (1994a) explored six possible sources of inter- and intra-country variations in selfemployment: (1) stages of economic development, (2) the bias of technological change, (3) changes in industry composition, (4) changes in female laborforce participation, (5) unemployment and (6) cultural factors. The paper also compared and contrasted selfemployment in OECD countries and in less developed countries. A major explanation for this diversity is the stage of economic development. While the tendency for the self-employment rate to decline with economic development was recognized as earlier as Kuzents (1966), this paper was the first attempt to estimate the statistical relationship between self-employment and economic development and to test a theoretical explanation for this relationship. Recent studies confirm that during the last 2 decades, the development of new technologies, and the emergence of new business models, has shifted from large corporations to small and new ventures (Jorgenson 2001; Audretsch and Thurik 2001). The literature shows that entrepreneurship contributes to economic performance by introducing innovation, enhancing rivalry and creating competition.

This line of research has greatly expanded in the past decade. An important paper by Carree et al. (2002) examined the relationship between economic development and business ownership for OECD countries, and reaffirmed the existence of a U-shaped relationship. In a second important paper, Wennekers et al. (2005) for the first time regressed GEM data for nascent entrepreneurship on the level of economic development. They also found support for the U-shaped relationship between countries at different stages of development (see Fig. 1).

However, this literature is not without limitations for the study of entrepreneurship and development. There are three observations. First, the U-shaped approach is useful in understanding the decline in self-employment in developing countries both across countries and over time, but not useful or at least less useful in explaining entrepreneurship (broadly defined). Second, the U-shaped approach is not very useful in explaining the role of entrepreneurship in developing countries in the efficiency-driven stage of development, either as they enter the efficiencydriven stage or leave the efficiency-driven stage (Acs and Amorós 2008). Finally, while the U-shaped framework was originally developed to understand the increase in entrepreneurship in high-income OECD countries, the model is also of limited value here, as many have questioned the U-shaped model. Carree et al. (2007) suggested that the L-shaped and U-shaped relationship between entrepreneurship and economic development couldn't be distinguished empirically because not all countries are in the upward part yet.

In some sense, the "chapter" on this line of research has reached a dead end. First, the U-shaped relationship does not provide an adequate explanation for the relationship between entrepreneurial activity and economic development. Second, the family of TEA measures, as well as other measures, reflects various activities or components related to "entrepreneurship" in both developed and developing countries (Acs et al. 2008), and can independently be inadequate for policy planning. 
Fig. 1 Nascent entrepreneurship versus per capita income, the U-curve. Source: Wennekers et al. (2005)

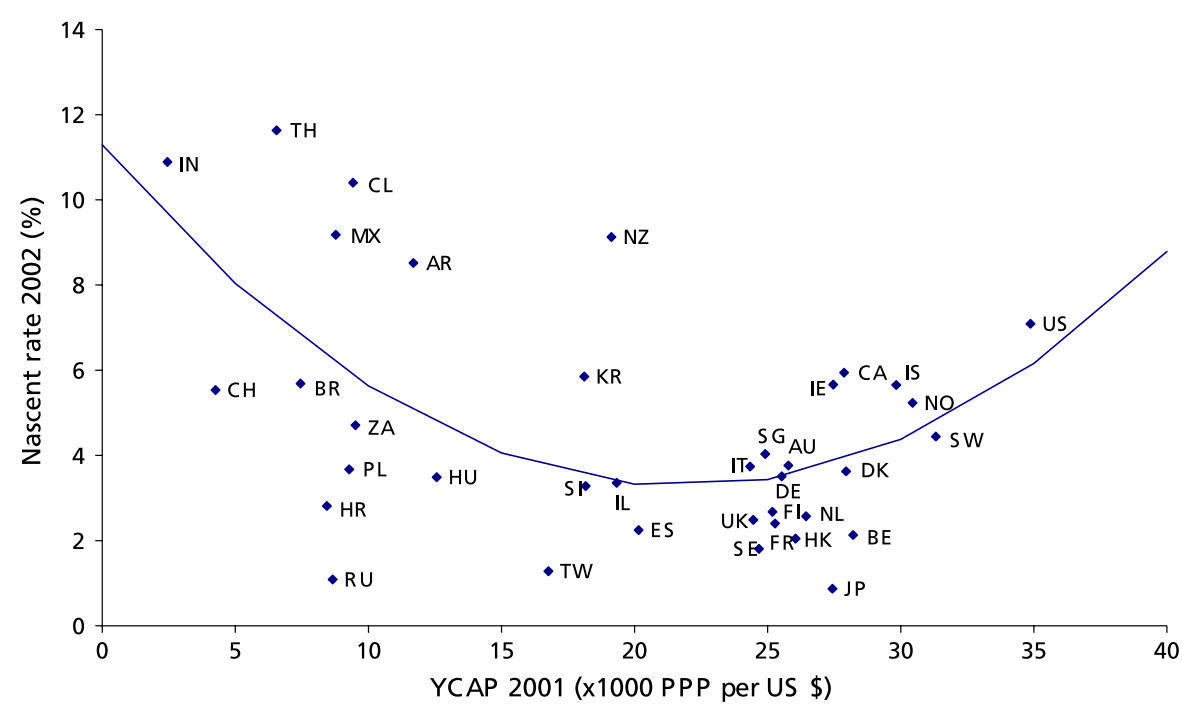

We have fitted a polynomial regression line to estimate the relationship between the opportunitynecessity entrepreneurship ratio and country income. While some fluctuations occur, a positive relationship appears between income level and the entrepreneurship ratio. In other words, countries where more entrepreneurship is motivated by an economic opportunity recognized than by necessity have higher levels of income. Immediately, the ranking of countries looks more reasonable. Brazil with an Opp/Nec of 1.1 is at the bottom, Japan is in the middle next to New Zealand, and Denmark is near the top.

Finally, if the U-shaped measures are inadequate for understanding entrepreneurship in developed and developing countries, can we rely on other measures? This introduction takes a step in this direction. Acs and Szerb (2008), Acs and Stenholm (2008), Ahmad and Hoffmann (2008) and Klapper et al. (2007), among others, are developing a new family of global entrepreneurship indices. For example, as shown in Fig. 3, the startup rate (Startuprte) is constructed as the total number of new corporations in a given year as a percentage of the total number of corporations in that year, between 2003 and 2005, and is based on data from the World Bank database. GDP per capita is based on purchasing power parity in US dollars. A more or less linear relationship is exhibited between entrepreneurship and economic development. ${ }^{5}$ That

\footnotetext{
5 http://www.ifc.org/ifcext/sme.nsf/Content/Entrepreneurship+ Database.
} 


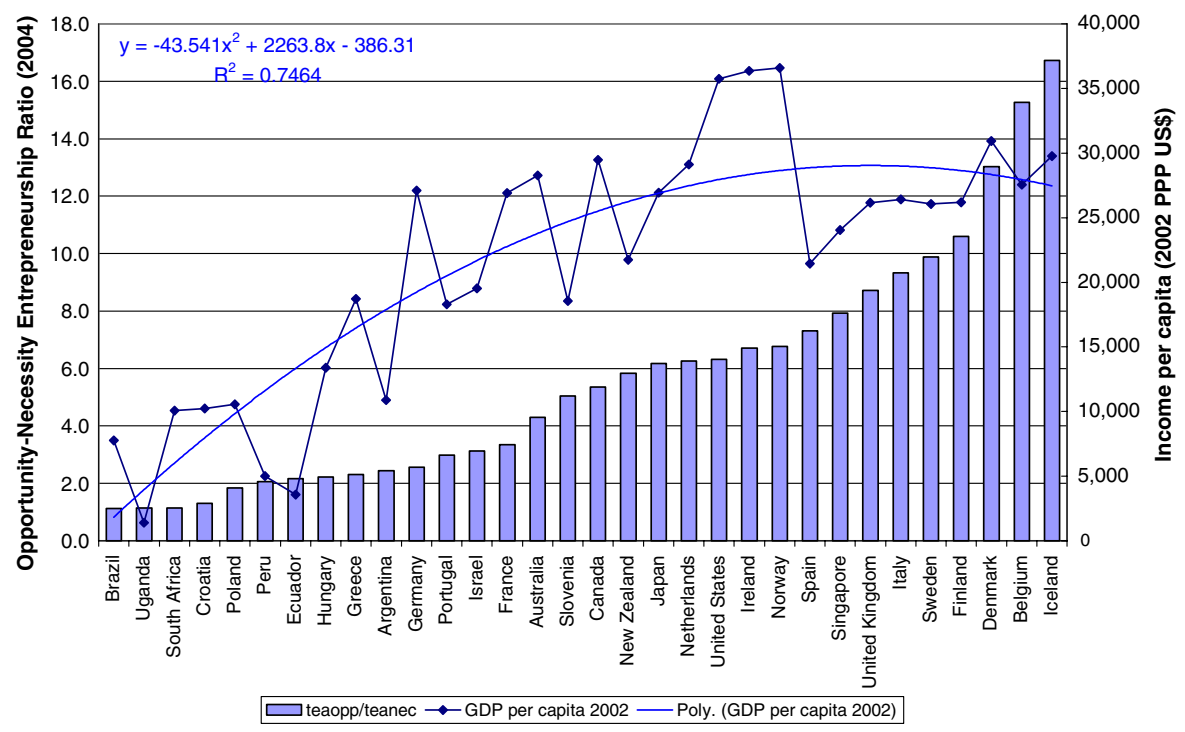

Fig. 2 Opportunity-necessity entrepreneurship ratio and income per capita. Note: entrepreneurship data are for 2004, income data for 2002 (the latest available). The sample of countries is defined by the Global Entrepreneurship Monitor database. Source: entrepreneurship data GEM 2004 Global Report,

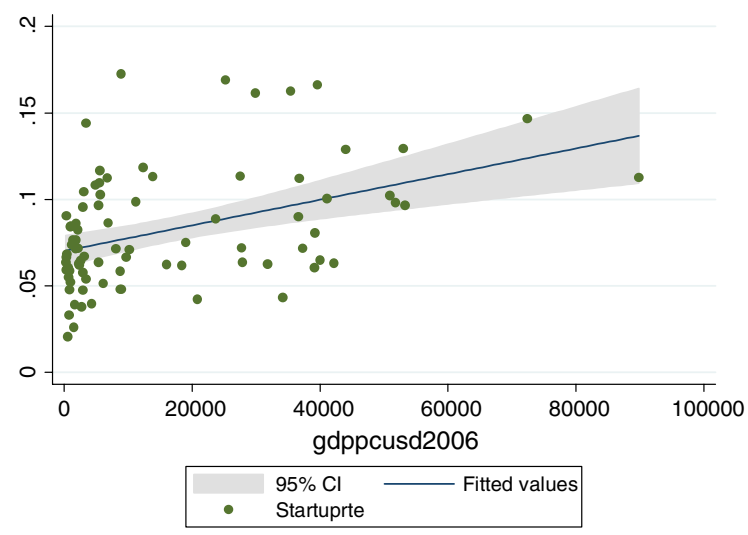

Fig. 3 World Bank startup data and income per capita. Source: Virgill (2008)

is, the index is not U-shaped, but rises with the level of development.

The Complex Global Entrepreneurship Context Index (CEC) uses 26 variables and measures entrepreneurial activity, strategy and attitudes for 54 countries, including developed and developing countries across the years 2003-2006 (see Fig. 4). The index takes a value from 0 to 1 and is plotted against income per capita based on purchasing power parity in US dollars. The results are again positively related with development. accessible at http://www.gemconsortium.org/category_list.asp? cid=163; income data United Nations Development Program, Human Development Report 2004, Table 13. Source: Acs (2006)

We can already measure entrepreneurship in developed and developing countries using existing measures, but they cannot easily be used in the same analysis. The development of measures like the World Bank Group Entrepreneurship Survey and the Complex Entrepreneurship Context index can be helpful in providing a broader and more encompassing picture of entrepreneurship. That is, the picture of the relationship between entrepreneurship and economic development appears to be more or less mildly S-shaped, not U-shaped. These measures can enable comparison of developed and developing countries in the same analysis (Virgill 2008).

We now turn to the papers in this special issue. The papers, in one way or another, address the issues surrounding the need for a global entrepreneurship index. The results of this section on the empirical relationship between entrepreneurship and economic development are revealing. The CEC index is broadly consistent with the factor-driven stage, the efficiencydriven stage and the innovation-driven stage of development (Porter et al. 2002). In other words, in the efficiency-driven stage, entrepreneurial activity is mildly increasing or relatively flat as necessity entrepreneurship is steadily reduced and innovation comes from the outside, since developing countries 
Fig. 4 The Complex Entrepreneurship Context CEC Index and Per Capita GDP. Source: Acs and Szerb (2008)

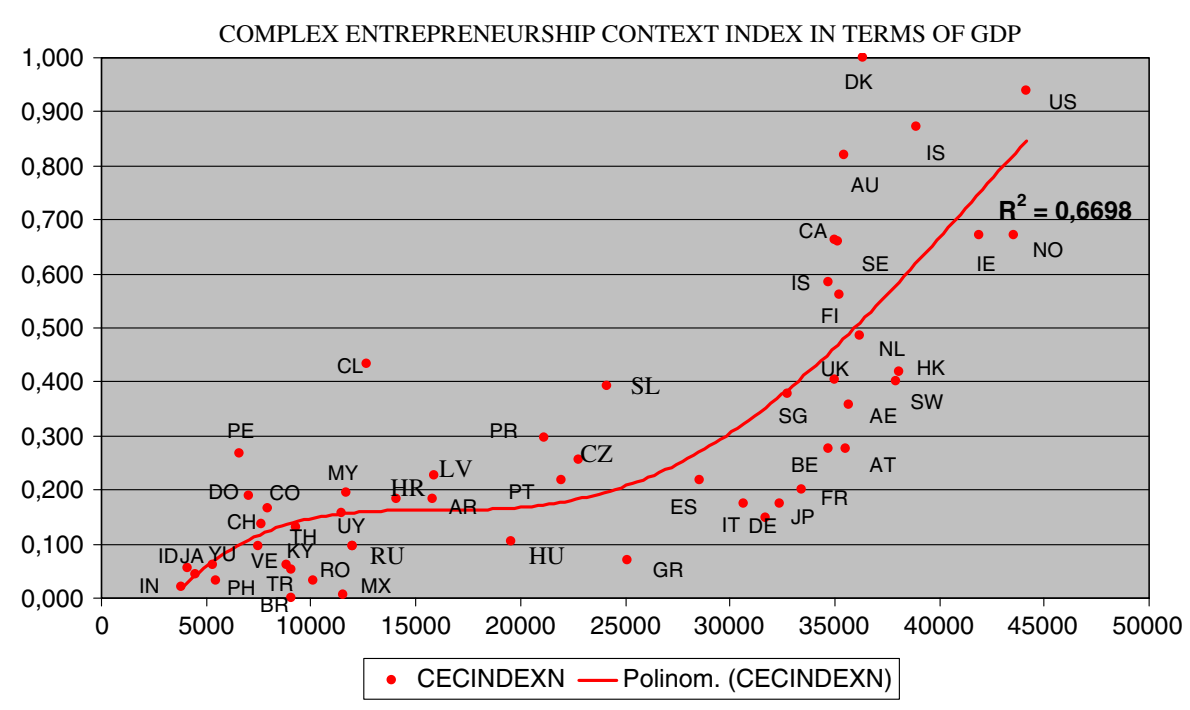

are far from the technological frontier (Acemoglu et al. 2007). In fact, this was demonstrated in the case of Ireland by Acs et al. (2007) and is addressed by two papers in this issue (De Clercq et al. 2008; Acs and Amoros 2008). The role of foreign direct investment becomes critical in creating efficiency in the efficiency-driven stage and knowledge spillovers to move a country to the technological frontier, which is synonymous with the innovation-driven economy (Baumol et al. 2006).

\section{Overview of the papers}

This special issue on the nexus between entrepreneurship, economic development and institutions is structured to present multiple levels of analysis, beginning with a broad conceptual model of the GEM framework that addresses the relationship between national-level business activity and institutional environments. The first paper, by Jonathan Levie and Erkko Autio, provides a theory-grounded examination of the GEM Model, and empirically tests several hypotheses that emerge from the model. In the second paper, Zoltan Acs, Sameeksha Desai and Leora Klapper present a cross-country study comparing two datasets on entrepreneurship against several important institutional variables. The third paper is authored by Dirk de Clerq, Jolanda Hessels and André van Stel, and examines the link between several macro-level environmental factors and entrepreneurs' export orientation across 34 countries. In a paper focused on the regional level, Zoltan Acs and José E. Amorós examine competitiveness and entrepreneurial dynamics in Latin America. Finally, Jolanda Hessels, Marco van Gelderen and Roy Thurik examine the drivers of entrepreneurial aspirations and start-up motives using data at the country level, including the role of economic development and welfare state institutional arrangements. Table 1 provides an overview of some of the main features of the papers in the special issue.

In the early days of GEM, a conceptual model including various Entrepreneurial Framework Conditions (EFCs) was developed. These EFCs indicate various conditions in which entrepreneurship is likely to flourish. It includes aspects such as access to finance, existence of government support policies for entrepreneurship, presence of entrepreneurship-specific training and education, and access to and transfer of R\&D and technology. The general idea of the GEM model is that the various EFCs affect entrepreneurial activity by enhancing opportunity recognition and skills perception. The Levie-Autio paper presents the GEM model and shows that there is a sound theoretical backing for the GEM conceptual model and EFCs. They ground the analysis in the Austrian tradition and examine how broad environmental conditions can affect the individual. Agents choose to engage in new business activity when they perceive opportunities and have the skills to start a business. However, a range of entrepreneurial framework conditions influence opportunity recognition and skills perception. 


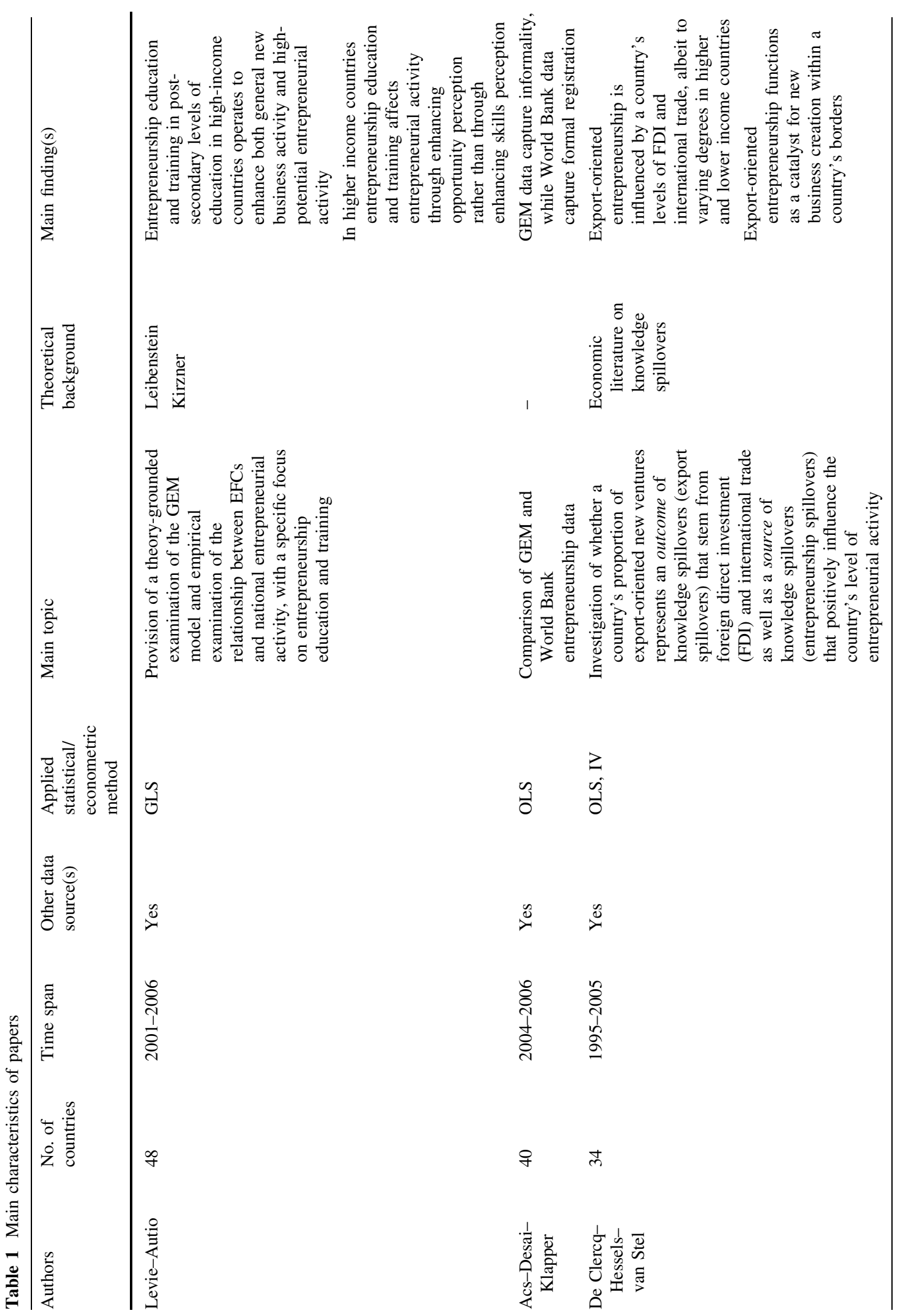




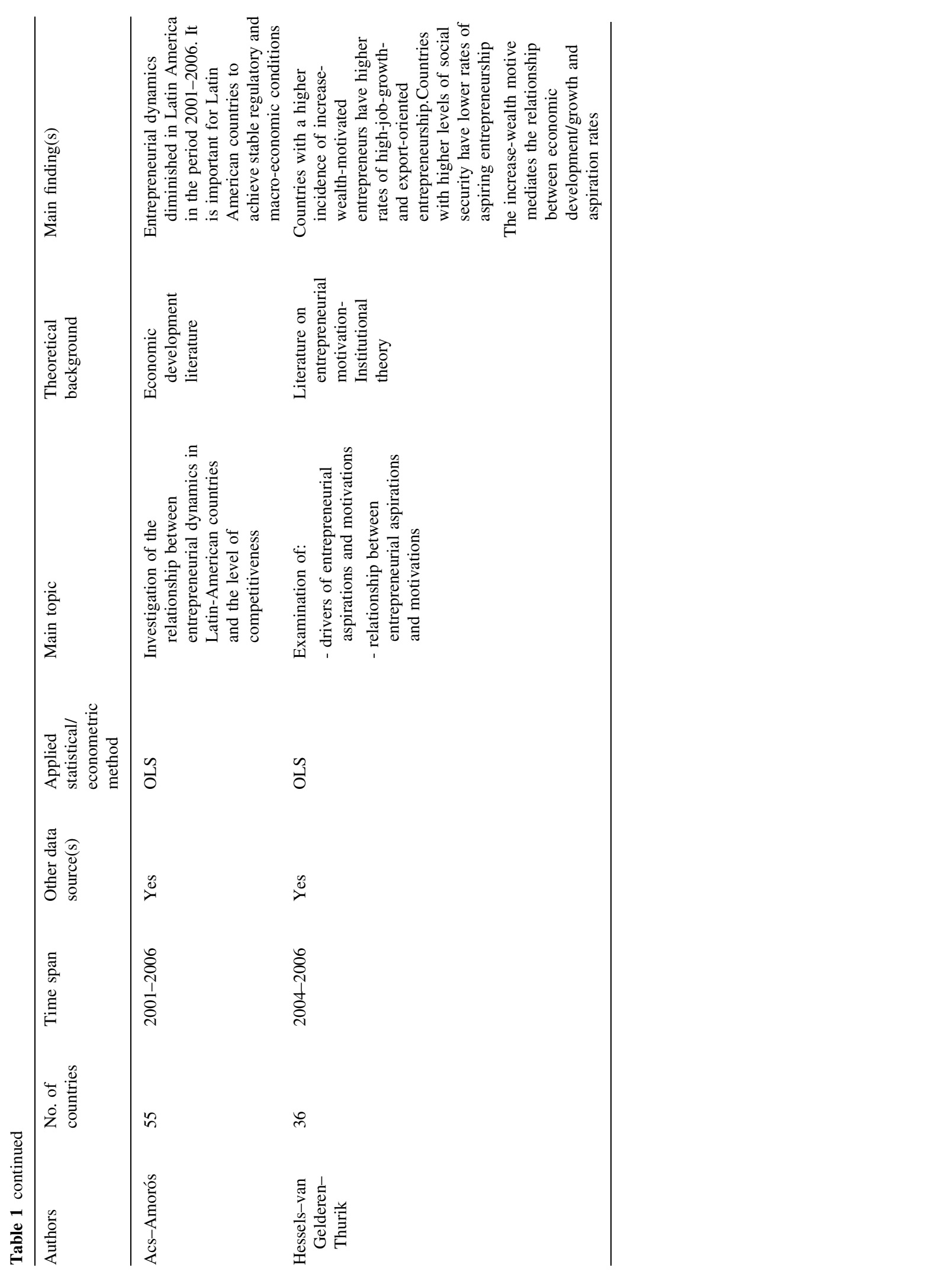


At the time when the GEM model was developed, proper testing of the suggested impact of the EFCs was not possible due to lack of data. The Levie-Autio paper is among the first to empirically test the impact of EFCs on early stage entrepreneurial activity and high-expectation entrepreneurship using data for the years 2000-2006. In their analysis, the authors focus specifically on the impact of one EFC, entrepreneurial education and training, on new business activity. This choice was guided by strong policy interest toward entrepreneurship education. Their main finding is that in high-income countries, post-secondary entrepreneurship education and training are positively related to the level of new business creation activity. It is also positively related to high-growth-expectation new-business activity, more by enhancing opportunity perception and less by enhancing skills perception. The importance of opportunity perception in determining action, rather than skills perception, is in line with the ideas of Kirzner (1979).

As mentioned above, comparable cross-country datasets on entrepreneurship were unavailable, and GEM was one of the first initiatives to collect harmonized international data. Recently, continued policy interested in entrepreneurship has led to several large-scale initiatives to collect data. These include Eurostat, OECD and the World Bank. The AcsDesai-Klapper paper provides a comparison of two datasets that are developed to capture entrepreneurial dynamics: GEM and the World Bank. They illustrate various differences between these two datasets. GEM, for example, focuses on early-stage entrepreneurial activity, and the World Bank data capture formal business registration. GEM uses a research design that has been harmonized across all participating countries, while cross-country harmonization has not yet been achieved in national business registries. GEM data tend to report significantly higher levels of early stage entrepreneurship in developing economies than does the World Bank business entry data, while the World Bank business entry data tend to be higher than GEM data for developed countries.

The authors undertake a number of empirical exercises linking both data sources to institutional variables and find that the magnitude of the difference in rates reported across countries in the two databases is related to local institutional and environmental conditions for entrepreneurs, after controlling for level of economic development. An explanation for this discrepancy is that the World Bank measures rates of entry in the formal economy, while GEM data are reflective of entrepreneurial "intent" and capture informality of entrepreneurship, particularly in developing countries. Therefore, this discrepancy might be interpreted as the spread between individuals who could potentially operate businesses in the formal sector - and those that choose to do so, i.e., GEM data may represent the potential supply of entrepreneurs, whereas World Bank Group data would represent the actual rate of entrepreneurship. The findings of this paper suggests entrepreneurs in developed countries have greater ease and incentives to incorporate, both for the benefits of greater access to formal financing and labor contracts, as well as for tax and other purposes not related to business activities.

Institutional and environmental factors may also be important for explaining country variation in the extent to which entrepreneurship is export-oriented. Exports are an important means through which small and new ventures are able to create value, generate growth and access new knowledge and technologies (Yeoh 2004). High-tech exports play an especially important role in economic growth in both low-income and high-income countries. Exporting firms generally perform better than non-exporting firms, and in particular tend to be more productive, more capital intensive, more innovative and more efficient (Clerides et al. 1998; Kneller and Pisu 2007). However, previous research with respect to the importance of export for national economies has strongly focused on established corporations and large multinational enterprises and has paid less relative attention to the role of start-ups in international markets.

An emerging body of research focuses on the effect of spillovers on the export decision of domestic firms, or export spillovers (Aitken et al. 1997; Greenaway et al. 2004; Kneller and Pisu 2007). Domestic firms may be more inclined to engage in export activities if exposed to other economic actors' international activities. The De Clercq-Hessels-van Stel paper focuses on such export spillover effects, with the assumption that export spillovers should be particularly relevant in the context of new ventures because emerging firms are more likely to benefit from (external) knowledge spillovers than their more established counterparts (Acs et al. 1994b; Henderson and Clark 1990). They draw on the knowledge spillover literature to suggest that a country's proportion of export-oriented new 
ventures, compared to its total number of new ventures, represents an outcome of knowledge spillovers (export spillovers) that stem from foreign direct investment (FDI) and international trade.

In addition, they suggest that a country's proportion of export-oriented new ventures is a source of knowledge spillovers (entrepreneurship spillovers) that positively influences the total level of entrepreneurial activity. The basic idea of such entrepreneurship spillovers is that exporting new ventures have preferential access to knowledge related to foreign markets and technologies that may generate novel insights into unexploited opportunities for new businesses. Also, export-oriented new ventures may act as role models; following the premises of institutional theory, individual economic actors may imitate the behavior of highly visible and successful peers. Such imitation may then provide support and legitimacy to entrepreneurship as a career choice, resulting in the creation of more new businesses within the country. In the analysis they distinguish between higher income and lower income countries. To test the hypotheses, macro-level data from 34 countries are used for the period 2002-2005.

They find that the relationship between FDI and international trade on the one hand and a country's proportion of export-oriented new ventures on the other differs for higher and lower income countries. Specifically, the results provide indications for export spillovers to new ventures for outward FDI and international trade in higher income countries. The findings also provide some support that a country's proportion of export-oriented new ventures functions as a catalyst for new business creation within its borders.

Various studies have shown that outcomes and antecedents of entrepreneurship differ for different groups of countries according to level of development. The Acs-Amorós paper starts with a review of the literature on economic development, focusing first on import substitution, followed by export promotion and finally the role of export promotion in developing countries. If exports are important for an economy, as suggested above, what role does entrepreneurship play? Using the traditional Ushaped model, the paper investigates how countries at the efficiency-driven stage of development are influenced by entrepreneurial behavior. They find that the traditional model of development holds when they test the U-shaped model. They find three insights. First, countries at the efficiency-driven level need to reduce necessity-driven entrepreneurship. Second, export-oriented entrepreneurs have a negative effect in developing countries, but a positive effect in developed countries. This suggests that exports in the efficiency-driven stage come from large firms and multinationals and not small firms. Third, high-impact entrepreneurs are also negatively related to development. In other words, high-impact firms operate more in the innovation-driven stage, and not the efficiency-driven stage.

Since its beginning, the GEM project has provided valuable insight into the nature of entrepreneurship by distinguishing between the opportunity and necessity motives. Since 2005, GEM data have made it possible to distinguish between independence and increased wealth within the opportunity motive. The Hessels-van Gelderen-Thurik paper investigates drivers of entrepreneurial aspirations and entrepreneurial motivations using country-level GEM data from 2005 and 2006. Aspirations have been shown to be a strong predictor of outcomes (Cassar 2007; Wiklund and Shepherd 2003). They estimate a twoequation model explaining aspirations using motivations and socio-economic variables, and explaining motivations using socio-economic variables. One of the main findings of the paper is countries with a higher incidence of increase-wealth-motivated entrepreneurs tend to have higher rates of job-growthoriented and export-oriented entrepreneurship. The country level of social security is found to relate negatively to the prevalence of innovative, jobgrowth- and export-oriented entrepreneurship.

Furthermore, they find that the increase-wealth motive mediates the relationship between country levels of economic development/growth and entrepreneurial aspirations. In particular, GDP per capita has a direct positive relationship with high job growth and export aspirations, but also an indirect negative relationship with these aspiration variables through its negative relationship with the increasewealth motive, as richer countries tend to have lower indices of increase-wealth-motivated entrepreneurs. GDP growth has a direct positive association with high job growth aspirations, and also an indirect positive relationship with high job growth and export aspirations through the increase-wealth motive. 
Table 2 Policy implications of the papers

Authors Policy implications

Levie-Autio

Acs-Desai-Klapper

De Clercq-Hessels-van Stel

Acs-Amorós
Post-secondary entrepreneurship education and training may be performing an 'eye-opening' role as it is found to have a positive effect on opportunity perception

The finding that entrepreneurship education and training affects new business activity primarily through enhancing opportunity perception, rather than start-up skills perception, has several implications for policy. The received literature on entrepreneurship education has tended to emphasize the role of education in the provision of instrumental skills to start up new firms. However, even though the perception of skills is directly associated with the level of new business activity in a country, education appears to have little role in fostering such skills. There are several possible explanations for this. One reason for this finding may be that education, post-secondary education in particular, tends to focus more on theory than practice. Thus, the observed lack of mediation may simply signal that entrepreneurship training and education are not practice-oriented enough to cultivate instrumental start-up skills within the population. An alternative explanation may be that the skill-set required to start new firms is too general and broad-based to be effectively taught in educational institutions, and they may be better acquired through work experience. A third possible reason may be that the necessary skill set may incorporate intangible social resources, such as entrepreneur-centric social capital, which are likely acquired through experience rather than through formal education and training. Finally, it may be that entrepreneurship education and training may not have advanced to the level of, say, medical schools in equipping students with the skills, knowledge and experience necessary to practice their profession. Whatever the reason, the findings suggest that the instrumental emphasis that pervades much of received literature on entrepreneurship education and training may be misplaced, at least in part

As entry barriers increase, the spread between the informal and the formal sector rises, as expected, and as entry procedures fall, the spread between the formal and informal sector falls. The implication is that barriers to entry are greater for corporate entrepreneurship than for young businesses that have not incorporated or for nascent entrepreneurs where they are in the process of starting a business. However, in developed countries, the spread between the informal and formal sectors not only decreases, but is often positive; i.e., the number of limited-liability companies is greater than the sum of sole proprietors and informal firms. This implies that it is at least as easy to start a limited liability company as a sole proprietorship

To benefit from export-spillover effects entrepreneurs aspiring to international growth should locate their business in areas where other international actors are concentrated

Governments in higher income countries could facilitate export spillovers by creating geographical zones specifically reserved for internationally oriented firms

Governments in lower income countries should focus on increasing the capacity for new ventures to absorb and exploit export spillovers. The findings illustrate the importance of role models for fostering entrepreneurship. Governments could facilitate entrepreneurship spillovers by enhancing contacts between potential role model entrepreneurs and individuals aspiring entrepreneurship

Latin American countries could move on two kinds of public policies: First, Latin American countries must work to achieve the efficiency-driven stage, which implies stable regulatory and macroeconomic conditions. This means continuing with the reduction of the unemployment and the necessity-based entrepreneurship. This kind of public policy - efficiency driver oriented - is indispensable, but not sufficient. If Latin American countries only follow "the natural tendency" and do not consider the promotion of entrepreneurship as a main concern on their policy agenda, they only will reduce the necessity-based entrepreneurship, but not achieve a higher growth for opportunity-based or international-oriented high-expectation entrepreneurship. The second kind of policy to gain more competitiveness (and plan the transition to the innovation-driven stage) is to advance a policy in which the innovative entrepreneurship should be promoted in order to create new and better firms with new business models, not only isolated or low value-added firms. Highexpectation entrepreneurial activities reflect a better performance of the competitiveness and economic development. This "way" implies that there must be better strategies to accelerate the growth rate and move more rapidly, thus allowing major innovation activity and a real impact of competitiveness and economic development on entrepreneurial dynamics, as was pointed out above with export processing zones integrated with entrepreneurship 
Table 2 continued

\begin{tabular}{ll}
\hline Authors & Policy implications \\
\hline $\begin{array}{l}\text { Hessels-van Gelderen- } \\
\text { Thurik }\end{array}$ & $\begin{array}{l}\text { To enhance aspiration levels among entrepreneurs, governments could aim to promote a higher } \\
\text { incidence of the increase-wealth motive among the population of entrepreneurs. Furthermore, } \\
\text { governments could also seek to enhance aspiration levels among independence-motivated and } \\
\text { necessity-motivated entrepreneurs } \\
\text { Since country's with higher levels of social security have lower rates of aspiring entrepreneurship, } \\
\text { governments face the challenge of designing social security systems in such a way that they } \\
\text { combine sufficient income security with incentives for innovation- and growth-oriented } \\
\text { entrepreneurial behavior }\end{array}$ \\
\hline
\end{tabular}

\section{Conclusion and policy implications}

The papers included in this issue contribute to understanding the nexus among entrepreneurship, economic development and institutions. Table 2 provides a detailed overview of various policy implications that follow from the papers. The conclusions of the papers in this special issue support the findings that the global economy is divided into thee stages-the factor-driven stage, the efficiencydriven stage and the innovation-driven stage-and that in order to understand entrepreneurship in all three stages, entrepreneurship data need to reflect the stages of development. This means moving away from simple measures of entrepreneurship across countries illustrating a U-shaped relationship to more complex measures, which are positively related to development and are S-shaped.

Several of the papers in this special issue have illustrated that institutional arrangements, including educational provisions, social security arrangements and other businesses, may affect various types of entrepreneurial activity directly or indirectly. Also, the papers illustrate that the impact of institutional arrangements on various types of entrepreneurial activity may differ depending on country level of economic development and even on the type of "entrepreneurship" measure examined. This collection of papers highlights the critical importance of the nature of entrepreneurship-for example, formal versus informal-and the ultimate purpose and effects of the activities-for example, necessity, opportunity, export-oriented, etc. For countries in the innovation-driven stage the results highlight that policy makers can positively affect entrepreneurship, including several ambitious types of entrepreneurship, by fostering entrepreneurship education and training, by stimulating outward FDI and international trade to facilitate export spillovers and by supporting role models. Countries in the factor-driven stage should work towards the efficiency-driven stage by focusing on achieving stable institutional and macro-economic environments and by increasing entrepreneurial capacity, e.g., by enabling individuals and businesses to absorb knowledge spillovers.

Finally, the papers reveal that complex interdependencies may exist between individual level factors, such as opportunity perception and start-up motivations on the one hand, and between national environmental or institutional conditions on the other hand. In particular, the results suggest individuallevel perceptions and motivations can have a mediating role between national environmental conditions on the one hand, and levels of entrepreneurial activity in general and ambitious entrepreneurial activity, on the other hand. The examination of institutional and environmental conditions is especially useful for public policy planning because they are more quickly sensitive to policy reforms, whereas individual-level factors may require more time to be affected by public policy.

Open Access This article is distributed under the terms of the Creative Commons Attribution Noncommercial License which permits any noncommercial use, distribution, and reproduction in any medium, provided the original author(s) and source are credited.

\section{References}

Acemoglu, D., Aghion, P., \& Zilibotti, F. (2007). Distance to frontier, selection and economic growth. Journal of the European Economic Association, 4, 37-74.

Acs, Z. J. (2006). How is entrepreneurship good for economic growth? Innovations, 1(1), 97-107. 
Acs, Z. J., \& Amorós, J. E. (2008). Entrepreneurship and competitiveness dynamics in Latin America. Small Business Economics, 31(3), this issue. doi:10.1007/s11187008-9133-y.

Acs, Z. J., \& Armington, C. (2006). Entrepreneurship, geography and American economic growth. Cambridge: Cambridge University Press.

Acs, Z. J., \& Audretsch, D. B. (1988). Innovation in large and small firms: An empirical analysis. American Economic Review, 78(4), 678-690.

Acs, Z. J., \& Stenholm, P. (2008). A global entrepreneurship index using GEM data. School of Public Policy, George Mason University, Mimeo.

Acs, Z., \& Szerb, L. (2007). Entrepreneurship, economic growth and public policy. Small Business Economics, 28(2/3), 109-122.

Acs, Z. J., \& Szerb, L. (2008). A complex global entrepreneurship context index (CEC). Faculty of business and economics, University of Pecs, Mimeo.

Acs, Z. J., \& Varga, A. (2005). Entrepreneurship, agglomeration and technological change. Small Business Economics, 24(3), 323-334.

Acs, Z., Audretsch, D., \& Evans, D. (1994a). Why does the self-employment rate vary across countries and over time? Discussion Paper No. 871, Center for Economic Policy Research, January 1994

Acs, Z. J., Audretsch, D. B., \& Feldman, M. (1994b). R\&D spillovers and recipient firm size. The Review of Economics and Statistics, 76(2), 336-340.

Acs, Z. J., Arenius, P., Hay, M., \& Minniti, M. (2005). 2004 Global entrepreneurship monitor. London UK and Babson Park, MA: London Business School and Babson College.

Acs, Z. J., Gorman, C., Szerb, L., \& Terjesen, S. (2007). Can the Irish miracle be repeated in Hungary? Small Business Economics, 28(2-3), 123-142.

Acs, Z. J., Desai, S., \& Klapper, L. F. (2008). What does "entrepreneurship" data really show? Small Business Economics, 31(3), this issue. doi:10.1007/s11187-0089137-7.

Ahmad, N., \& Hoffmann, A. N. (2008). A framework for addressing and measuring entrepreneurship. OECD Statistics Working Paper, 2. Retrieved May 9, 2008, from: http://ssrn.com/abstract=1090374.

Aitken, B., Hanson, G. H., \& Harrison, A. E. (1997). Spillovers, foreign investment and export behavior. Journal of International Economics, 43(1-2), 103-132.

Aquilina, M., Klump, R., \& Pietrobelli, C. (2006). Factor substitution, average firm size and economic growth. Small Business Economics, 26(3), 203-214.

Audretsch, D. B. (2007). Thee entrepreneurial society. Oxford: Oxford University Press.

Audretsch, D. B., \& Thurik, A. R. (2001). What's new about the new economy? From the managed to the entrepreneurial economy. Industrial and Corporate Change, 10(1), 267-315.

Autio, E. (2007). Global entrepreneurship monitor: 2007 Global report on high growth entrepreneurship. Wellesley, MA/London: Babson College and London Business School.
Baumol, W. (2002). The free-market innovation machine: Analyzing the Growth Miracle of Capitalism. Princeton: Princeton University Press.

Baumol, W. J., Litan, R. E., \& Schramm, C. J. (2006). Good capitalism bad capitalism: And the economics of growth and prosperity. New Haven: Yale University Press.

Blau, D. (1987). A time-series analysis of self-employment in the United States. Journal of Political Economy, 95(3), 445-467.

Carree, M. A., van Stel, A. J., Thurik, A. R., \& Wennekers, A. R. M. (2002). Economic development and business ownership: An analysis using data of 23 OECD countries in the period 1976-1996. Small Business Economics, 19, 271-290.

Carree, M., van Stel, A., Thurik, R., \& Wennekers, S. (2007). The relationship between economic development and business ownership revisited. Entrepreneurship and Regional Development, 19(3), 281-291.

Cassar, G. (2007). Money, money, money? A longitudinal investigation of entrepreneur career reasons, growth preferences and achieved growth. Entrepreneurship \& Regional Development, 19(1), 89-107.

Clerides, S. K., Lach, S., \& Tybout, J. R. (1998). Is learning by exporting important? Micro-dynamic evidence from Colombia, Mexico, and Morocco. The Quarterly Journal of Economics, 113(3), 903-947.

De Clercq, D., Hessels, J., \& van Stel, A. (2008). Knowledge spillovers and new ventures' export orientation. Small Business Economics, 31(3), this issue. doi:10.1007/s11187008-9132-z.

Easterly, W. (2001). The lost decade: Developing countries' stagnation in spite of policy reform 1980-1998. Journal of Economic Growth, 6, 135.

Evans, D., \& Leighton, L. S. (1989). The determinants of changes in U.S. Self-employment, 1968-1987. Small Business Economics, 1(2), 111-119.

Greenaway, D., Sousa, N., \& Wakelin, K. (2004). Do domestic firms learn to export from multinationals? European Journal of Political Economy, 20(4), 1027-1043.

Henderson, R., \& Clark, K. (1990). Architectural innovation: The reconfiguration of existing product technologies and the failure of established firms. Administrative Science Quarterly, 35(1), 9-30.

Hessels, J., Van Gelderen, M., \& Thurik, R. (2008). Entrepreneurial aspirations, motivations and their drivers. Small Business Economics, 31(3), this issue. doi:10.1007/s11187008-9134-х.

Jorgenson, D. W. (2001). Information technology and the U.S. economy. American Economic Review, 91(1), 1-32.

Kirzner, I. M. (1979). Perception, opportunity and profit: Studies in the theory of entrepreneurship. Chicago: University of Chicago Press.

Klapper, L., Amit, R., Guillén, M. F., \& Quesada, J. M. (2007). Entrepreneurship and firm formation across countries. Development Research Group Working Paper No.XX. Washington, DC: World Bank

Kneller, R., \& Pisu, M. (2007). Industrial linkages and export spillovers from FDI. The World Economy, 30(1), 105-134.

Kuzents, S. (1966). Modern economic growth. New Haven: Yale University Press. 
Levie, J., \& Autio, E. (2008). A theoretical grounding and test of the GEM model. Small Business Economics, 31(3), this issue. doi:10.1007/s11187-008-9136-8.

North, D. (1990). Institutions, institutional change and economic performance. Cambridge: Cambridge University Press.

Porter, M. E. (1990). The competitive advantage of nations. New York: Macmillan.

Porter, M., Sachs, J., \& McArthur, J. (2002). Executive summary: Competitiveness and stages of economic development. In M. Porter, J. Sachs, P. K. Cornelius, J. W. McArthur, \& K. Schwab (Eds.), The global competitiveness report 2001-2002 (pp. 16-25). New York: Oxford University Press.

Reynolds, P., Bosma, N., Autio, E., Hunt, S., De Bono, N., Servais, I., et al. (2005). Global entrepreneurship monitor: Data collection design and implementation, 1998-2003. Small Business Economics, 24(3), 205-231.

Roper, S., \& Love, J. H. (2002). Innovation and export performance: Evidence from the UK and German manufacturing plants. Research Policy, 31(7), 1087-1102.

Schramm, C. J. (2006). The entrepreneurial imperative. New York: Harper Collins.

Schultz, T. (1988). Education investment and returns. In H. Chenery \& T. N. Srinivasan (Eds.), Handbook of development economics (pp. 543-630). Amsterdam/New York: North-Holland.

Schumpeter, J. A. (1934). The theory of economic development. Cambridge, MA: Harvard University Press.

Scott, W. R. (1995). Institutions and organizations. Thousand Oaks, CA: Sage.
Sterlacchini, A. (1999). Do innovative activities matter to small firms in non-R\&D-intensive industries? An application to export performance. Research Policy, 28(8), 819-832.

Sternberg, R., \& Wennekers, S. (2005). The determinants and effects of new business creation using global entrepreneurship monitor data. Small Business Economics, 24(3), 193-203.

Syrquin, M. (1988). Patterns of structural change. In Handbook of Development Economics (pp. 203-273). Amsterdam: New York: North-Holland.

UNCTAD. (2006). World investment report 2006. FDI from developing and transition economies: Implications for development. New York/Geneva: United Nations.

Virgill, N. (2008). Export processing zones: Tools of development or reform delay? Dissertation, George Mason University.

Wakelin, K. (1998). Innovation and export behavior at the firm level. Research Policy, 26(7-8), 829-841.

Wennekers, A. R. M., \& Thurik, A. R. (1999). Linking entrepreneurship and economic growth. Small Business Economics, 13(1), 27-55.

Wennekers, S., van Stel, A., Thurik, A. R., \& Reynolds, P. (2005). Nascent entrepreneurship and the level of economic development. Small Business Economics, 24(3), 293-309.

Wiklund, J., \& Shepherd, D. (2003). Aspiring for, and achieving growth: The moderating role of resources and opportunities. Journal of Management Studies, 40(8), 1919-1941.

Williamson, O. E. (1998). The institutions of governance. The American Economic Review, 88(2), 75-79. 